Agro-Science Journal of Tropical Agriculture, Food, Environment and Extension Volume 12 Number 2 May 2013 pp. $20-27$

ISSN 1119-7455

\title{
EFFECTS OF NEEM SEED CAKE ON THE GROWTH AND YIELD OF OKRA (ABELMOSCHUS ESCULENTUS (L.) MOENCH) IN ILORIN, NORTH CENTRAL NIGERIA.
}

\author{
Eifediyi, E. $\mathbf{K}^{\mathbf{1}}$,, Ahamefule H. $\mathbf{E}^{\mathbf{1}}$ and Remison, S. $\mathbf{U}^{\prime}$ \\ ${ }^{(1)}$ Department of Agronomy, University of Ilorin, Ilorin, Nigeria \\ ${ }^{(2)}$ Department of Crop Science, Ambrose Alli University, Ekpoma Edo State, Nigeria
}

\begin{abstract}
Soils of the Southern Guinea Savanna are generally inherently infertile owing to low vegetation cover, soil erosion and low organic matter content occasioned by constant bush fire. Consequently, farmers move close to streams and rivers in the dry season where okra is cultivated by irrigation. Field experiments were conducted at the Teaching and Research Farm of the University of Ilorin, Ilorin Nigeria during the 2012 and 2013 cropping seasons to evaluate the effects of neem seed cake on the performance of okra. The neem seed cake was incorporated into the soil one week before planting of the okra seeds at the rate of $0,1,2,3$ and 4 t/ha. The experiment was laid out as a randomized complete block design replicated three times. Data were collected on growth parameters (plant height, number of leaves, and number of branches) and yield parameters (fruit length and girth, number of fruits per plant, fruit weight per plant and fruit weight per hectare). The result of the experiments indicated that applying neem seed cake significantly affected the growth and yield parameters that were evaluated. Applying neem seed cake however gave the highest yield at 3t/ha. Percentage mean for the two years combined was 75.81 over the control. The results generally indicated that neem seed cake can be used when inorganic fertilizers are unavailable or beyond the reach of peasant farmers for improved crop growth and development.
\end{abstract}

Keywords. Neem seed cake, soil properties, growth and yield of okra

\section{INTRODUCTION}

Okra (Abelmoschus esculentus (L.) Moench) which belongs to the Malvaceae family is the fourth most popular fruit vegetable in Ghana after tomatoes, peppers and garden eggs; In Sudan, the crop is the fourth most important vegetable whereas in Cameroun, is the second most important vegetable in the market after tomatoes (Schippers, 2000). The crop is also an important crop in India, and in Nigeria alone, it occupies 1.5 million hectares (IFA, 1992). The tender fruits which contain minerals, vitamins and high mucilage content are used in thickening soups and stews (Udo and Akpan, 2002); young shoots and flowers are also used as food (Ndaeyo et al., 2005); young immature fruits are an important vegetable consumed cooked or fried (Grubben and Denton, 2004); mucilage is used medicinally as plasma replacement or blood volume expander (Grubben and
Denton, 2004). The crop has a yield potential of $30-$ 40t/ha if growth factors are applied (IFA, 1992), but there is a wide gap between this potential yield and realized yield. There is a need to bridge the gap between this potential yield and realized yield. The obstacle towards the realization of this set objective is inadequate soil nutrients.

Farmers in the tropics have adopted the use of inorganic fertilizers but intensive use of this over time has been reported to constitute a setback to soil (Phicot et al., 1981; Isherwood, 2000); it pollutes the underground water resources (Uma Singh and Pokhriyal, 1997); increases soil acidity, nutrient imbalance and soil degradation (Kang and Juo, 1980). However, vegetables that are cultivated by using organic manures are gaining importance because of less chemical residues, better taste as well as their 
effect on soil health and environment (Sunanda Rani and Mallareddy, 2007). Although many organic sources are available, their nutrient supplying capacity is not similar. It is therefore pertinent to evaluate the effects of these organic materials on the performance of individual crops. Sivaprakashan (1991) opined that plant debris, farm yard manure and compost improved crop productivity by improving nutrient status and soil tilth, besides increasing microbial activity in the soil.

Similarly, nutrient supply through oil based cakes are also a form of organic manure that will not only reduce the dependence on chemical fertilizers but also improve the soil structure, encourage the growth and activity of beneficial organisms in the soil, alleviate the deficiency of secondary and micronutrients and sustain higher productivity due to improved soil health (Tiwari, 2002; Singh et al., 2006).

Majority of studies have indicated that crop production has benefited from the application of organic residues due to the possibility of recycling organic matter, $\mathrm{N}, \mathrm{P}$ and $\mathrm{K}$ and other nutrients (Adeoye et al., 2008). Asiegbu (1987) posited that the application of 10t/ha of poultry manure significantly increased the number of fresh pod weight in okra. Smith et al. (2001) reported that the use of soil amendment under a humid environment significantly increased the growth and yield of okra pods.

The soils of southern guinea savanna are inherently infertile because of low vegetation cover, soil erosion and low organic matter content occasioned by constant bush fire. There is therefore a need for the application of external nutrient inputs in the form of neem seed cake for the growth of vegetables as well as other arable crops. Neem seed cake is the residual matter left after neem seed kernels are crushed to extract neem seed oil. Neem seed cake contains more nitrogen $(2-5 \%)$, phosphorus $(0.5-1.0 \%)$, potassium $(1-2 \%)$, calcium $(0.5-3 \%)$ and magnesium $(0.3-$ $1.0 \%$ ) than farmyard manure or sewage sludge (Radwansksi and Wickens, 1981). Neem seed cake not only provides nutrition to the plant, but controls soil borne pests particularly nematodes and acts as a nitrification inhibitor. It also increases the population of earthworms and produces organic acids, which helps in the reduction of soil alkalinity (Korah and Shingte, 1968). Uma Singh and Gurumurti (1984) suggested the use of neem cake as organic fertilizer. Soon and Bottrel (1994) asserted that neem seed cake acts as natural fertilizer with pesticidal properties whereas Parmar (1986) reported that neem seed cake exhibits insecticidal properties, nitrification retardation and inhibitor of pesticide degradation. Singh et al. (2006) observed that neem seed cake increased the number of branches, root length and dry matter weight of crops after ten months compared to the control. These properties make NSC ideal for amelioration of degraded soils. The objective of the study was to evaluate the effects of neem seed cake on the soil properties, growth and yield of okra.

\section{MATERIALS AND METHODS}

The experiments were conducted during the 2012 and 2013 cropping seasons at the Teaching and Research Farm of the University of Ilorin, Ilorin, Nigeria on Latitude $8^{\circ} 49^{\prime}$ and Longitude $4^{\circ} 49^{\prime}$ East in a Southern Guinea Savanna zone. The area is characterized by a bimodal rainfall pattern, a long rainy season from late April to July and a short rainy period that extends from September to late October after a dry spell in August and a dry season (November - March). The site was a three-year fallow land after it was cropped to maize and cassava for two years prior to the establishment of the experiments. Soil samples were collected from 0-30 cm depth from twenty locations prior to planting and application of neem seed cake within the experimental plots, were bulked and a composite was taken for physio-chemical characterization. Soil $\mathrm{pH}$ was measured (soil: water ratio, 1:2) using a glass electrode; total $\mathrm{N}$ content was determined by micro - Kjeldahl method (Bremner, 1965); available phosphorus was determined following Bray No 1 (1 N NH4F $+0.5 \mathrm{~N}) \mathrm{HCl}$ extractant by vanadomolybdophosphoric acid method (Kuo, 1996), organic carbon was determined using the modified Walkley - Black method (Nelson and Sommers, 1996) and exchangeable bases extraction done using $1 \mathrm{~N}$ ammonium acetate, exchangeable $\mathrm{K}$ and $\mathrm{Na}$ were determined using flame photometry while $\mathrm{Ca}$ and $\mathrm{Mg}$ were analyzed by Atomic Absorption spectrophotometry. Land was cleared of existing vegetation, ploughed, harrowed and ridges were made. Each plot was made of two ridges measuring 5 metres separated by a 0.5 metre avenue. The neem seed cake (NSC) was manually worked into the soil using a hoe one week before sowing and sowing of the seeds was done on the $25^{\text {th }}$ of July, 2012 and 25th of July 2013 using NHAc variety from NIHORT, Ibadan at a spacing of $30 \times 30 \mathrm{~cm}$. Three hand weedings were carried out at 3, 6 and 9 weeks after planting. Data collected on five tagged plants were vegetative parameters (plant height, number of leaves, and number of branches) and yield parameters (number of fruits per plant, fruit weight per plant, and fruit length and girth and fruit weight per hectare). The plant height was assessed by measuring from the base of the plant to the terminal point of the stem; the number of branches and leaves were assessed by visual count of the green leaves and branches; fruit length and girth were measured by using a digital caliper; number of pods per plant was assessed by counting the number of fruits per plant at each harvest and fruit weight per 
plant was measured by using a sensitive balance and the weight per hectare was extrapolated from the weight per plant. Analysis of variance (ANOVA) for all measurements were performed using Genstat software version 12 statistical packages for randomized complete block design (RCBD) and mean separation was done based on the work of Steele and Torrie ( 1980).

\section{RESULTS AND DISCUSSION}

The result of the soil analysis indicated that prior to planting in 2012, the soil $\mathrm{pH}$ was slightly acidic, the organic carbon content was low and after cropping, the organic carbon content was moderate ( Table 1). This could be due to the incorporation of neem seed cake that is a rich source of organic carbon hence organic matter content, which is a rich source of plant nutrients. This is in agreement with the findings of Shivakumar et al. (2011) who reported an increase in organic carbon content from 0.03 to $0.06 \%$ after the application of neem seed cake in finger millet. Wilkinson (1979) also reported that the beneficial effect of organic manure could be attributed to an increase in organic matter content as result of regeneration of $\mathrm{CO}_{2}$ during organic development. Neem seed cake acts as a nutrient reservoir providing favorable $\mathrm{pH}$, aeration and improving other physical and chemical properties of the soil (Uma Singh and Pokhriyal, 1997). This was in agreement with the findings of Rizvi et al.(2013) who posited that neem seed cake is a rich source of organic matter that can improve the soil physical properties and its fertility. Organic matter acts as nutrient reservoirs and on decomposition releases organic acids and the crops might absorb ions through their roots for the entire growth period leading to higher yields (Kumar $e t$ al., 2009). The total nitrogen content before cropping and the incorporation of neem seed cake was very low (Table 1). At the end of the first cropping season, the nitrogen content was moderately increased from (0.08 to 0.13 ) indicating an increase in the soil fertility status because of NSC incorporation. Neem seed cake improved the soil organic matter content and fertility of the soil (Azim et al., 2011). Aderni (2006) opined that the application of organic manure significantly increased level of organic carbon, nitrogen as compared to the application of inorganic fertilizer. The application of neem seed cake could have improved the availability of nutrients to the crop by enhancing the mineralization and supply of readily available nutrients to the soil microbial community (Yusuf et al., 2011). Organic manures like oil seed cakes supply micronutrients beneficial to crop growth and productivity (Das et al., 2004). The increased soil nutrients after the first cropping could be attributed to the nutrient status of the neem seed cake. Similar results have been observed by Shivakumar et al. (2011) using neem seed cake on finger millet and Lei Meng et al. (2005) using organic manures. The phosphorus content before and after incorporation was low but the $\mathrm{K}$ content which was very low before cropping increased because of NSC incorporation (Table 1). The $\mathrm{Ca}$ and $\mathrm{Mg}$ contents were low before and after cropping. The results of the soil analysis indicated the presence of macro and micronutrients in neem seed cake that can be harnessed by crop plants. Tiyagi and Ajaz (2004) reported that oil seed cake increased microbial activity and brought about increased conversion of nitrogen to nitrate form which ultimately increased metabolic activities of plant and then plant growth.

Table 1: Soil properties of the experimental site before and after cropping in 2012 and 2013

\begin{tabular}{lllllllll}
\hline & & \multicolumn{2}{c}{ Percent } & \multicolumn{3}{c}{ Ppm } & \multicolumn{3}{c}{$\mathrm{cmol} / \mathrm{kg}$} \\
\hline Year & Soil $\mathrm{pH}$ & Org C & Org. matter & Total N & P & $\mathrm{K}$ & $\mathrm{Ca}$ & $\mathrm{Mg}$ \\
$2012 \mathrm{a}$ & 6.2 & 0.59 & 1.02 & 0.08 & 3.43 & 0.12 & 2.15 & 0.90 \\
$2012 \mathrm{~b}$ & 6.5 & 1.01 & 1.88 & 0.13 & 3.28 & 0.21 & 3.00 & 0.84 \\
2013 & 6.6 & 0.61 & 1.05 & 0.07 & 3.32 & 0.14 & 2.20 & 0.70 \\
\hline
\end{tabular}

a. Before initial cropping, b. End of first ar cropping

Table2: Effects of neem seed cake on the growth parameters of okra at 4, 6, 8 and 10 weeks after planting in 2012.

\begin{tabular}{|c|c|c|c|c|c|c|c|c|c|c|c|c|}
\hline \multirow[t]{2}{*}{ NSC t/ha) } & \multicolumn{2}{|c|}{ Plant height $(\mathrm{cm})$} & \multirow{2}{*}{$\begin{array}{c}\text { WAP } \\
10\end{array}$} & & \multicolumn{2}{|c|}{ No of leaves/plant } & \multirow{2}{*}{$\begin{array}{l}\text { WAPP } \\
10\end{array}$} & & \multicolumn{4}{|c|}{ No of branches/plant WAP } \\
\hline & 4 & 8 & & & 4 & 6 & & & 4 & 6 & $8 \quad 10$ & \\
\hline $\mathbf{0}$ & 15.92 & 17.61 & 23.02 & 37.59 & 11.00 & 13.33 & 15.72 & 16.67 & 3.00 & 4.00 & 4.78 & 5.78 \\
\hline 1 & 18.19 & 19.59 & 25.86 & 43.70 & 11.67 & 14.20 & 16.26 & 19.00 & 4.33 & 5.00 & 5.83 & 6.31 \\
\hline 2 & 18.78 & 20.97 & 27.24 & 46.72 & 13.67 & 14.40 & 16.96 & 20.10 & 5.33 & 6.67 & 7.37 & 6.68 \\
\hline 3 & 19.32 & 24.14 & 32.21 & 57.92 & 15.00 & 15.71 & 18.64 & 23.60 & 6.00 & 7.33 & 8.80 & 7.87 \\
\hline 4 & 20.32 & 24.20 & 32.22 & 57.27 & 15.33 & 16.13 & 18.67 & 23.48 & 6.00 & 7.33 & 8.41 & 7.95 \\
\hline Mean & 18.50 & 21.30 & 28.11 & 48.64 & 13.33 & 14.75 & 17.25 & 20.57 & 4.933 & 6.01 & 7.04 & 6.92 \\
\hline $\operatorname{LSD}(0.05)$ & 1.921 & 1.769 & 4.179 & 4.805 & 0.688 & 1.729 & 0.822 & 1.507 & 1.396 & 1.002 & 0.930 & 0.408 \\
\hline
\end{tabular}

N S C $=$ Neem seed cake 
Effects of Neem Seed Cake on the Growth and Yield of Okra

\section{Growth parameters of okra}

The data on the growth parameters in 2012 of okra at 4, 6,8 and 10 weeks after planting are presented (Table 2 ). The result indicated that at the four sampling periods of 4, 6, 8 and 10WAP, there was a significant $(\mathrm{P}<0.01)$ increase in plant height, number of leaves and number of branches with increase in the rates of neem seed cake application. There was a significant response of okra to the different levels of NSC application in the vegetative and yield parameters. This could be attributed to the contribution of the NSC, which is a form of organic amendment to supplying the plants with macro and micronutrients, which are essential for the growth, development and yield of okra. NSC brings about improvement in plant growth due to better soil nutrition status (Kumar and Khanna, 2006). Olaniyi et al. (2005) reported significant increase in plant height and number of leaves of okra when OMF, a type of organic manure was applied in Ogbomoso in South West Nigeria and optimum result was recorded at 4 t/ha. Ikeh et al. (2013) observed that the application of $8 \mathrm{t} / \mathrm{ha}$ of poultry manure gave significant high number of fruits and yield of chilli pepper.

The data on the growth parameters of okra in 2013 at 4, 6, 8 and 10 weeks after planting are presented in (Table $3)$. The data on plant height of okra indicated that the plant height increased significantly $(\mathrm{P}<0.01)$ at 4,6 and 8 WAP but at 10 WAP, there was no significant response to the applied neem seed cake. The data on the number of leaves indicated that as the rates of application of neem seed increased, there was a significant $(\mathrm{P}<0.05)$ increase in the number of leaves across the four sampling periods of $4,6,8$ and 10 weeks after planting. Data on the number of branches of okra showed that as the neem seed cake increased, there was a significant increase at 4,8 and 10 WAP except at the 6WAP when the response to neem seed cake was not significant. This is in agreement with the findings of Uma Singh et al. (1986) who posited that neem seed cake increased the number of branches of crops compared to the control.

Table 3: Effects of neem seed cake on the growth parameters of okra at 4, 6, 8 and 10 weeks after planting in 2013

\begin{tabular}{|c|c|c|c|c|c|c|c|c|c|c|c|c|}
\hline \multirow[t]{2}{*}{$\begin{array}{l}\text { N S C } \\
\text { (t/ha) }\end{array}$} & \multicolumn{4}{|c|}{$\begin{array}{l}\text { Plant height }(\mathrm{cm}) \\
\text { WAP }\end{array}$} & \multicolumn{4}{|c|}{$\begin{array}{l}\text { No of leaves/plant } \\
\text { WAP }\end{array}$} & \multicolumn{4}{|c|}{$\begin{array}{l}\text { No of branches/plant } \\
\text { WAP }\end{array}$} \\
\hline & 4 & 6 & 10 & & 4 & 6 & 10 & & 4 & 6 & 10 & \\
\hline 0 & 12.69 & 14.60 & 20.80 & 39.74 & 10.33 & 10.67 & 13.17 & 16.67 & 2.33 & 4.67 & 5.44 & 5.53 \\
\hline 2 & 13.69 & 15.96 & 24.07 & 45.07 & 12.33 & 12.62 & 14.87 & 20.10 & 3.67 & 5.33 & 6.21 & 7.21 \\
\hline 3 & 14.03 & 16.30 & 27.64 & 46.45 & 14.67 & 13.18 & 15.71 & 23.60 & 4.33 & 6.33 & 6.77 & 8.60 \\
\hline 4 & 13.87 & 16.57 & 28.26 & 45.75 & 14.67 & 13.25 & 15.74 & 23.48 & 4.67 & 6.33 & 6.80 & 8.87 \\
\hline Mean & 13.47 & 15.72 & 24.71 & 43.83 & 12.73 & 12.36 & 14.70 & 20.57 & 3.67 & 5.60 & 6.16 & 7.38 \\
\hline $\operatorname{LSD}(0.05)$ & 0.361 & 1.159 & 2.761 & NS & 1.975 & 0.791 & 0.811 & 1.847 & 0.729 & NS & 0.477 & 0.837 \\
\hline
\end{tabular}

Table 4: Effects of neem seed cake on the yield and yield components of okra in 2012

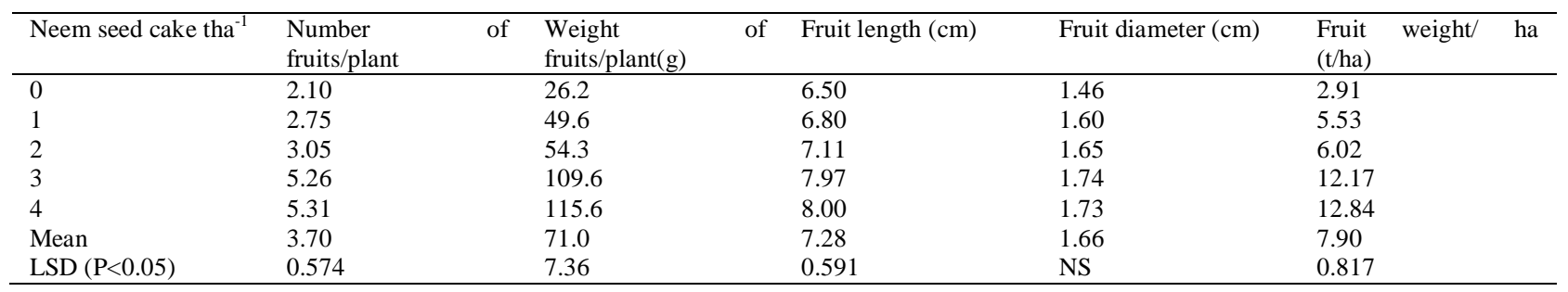


Neem seed cake is quick acting, provides a slow and steady nourishment and improves yield and quality of crops (Gaur et al., 1992, Meena et al.,2009). Fruit harvesting started at six weeks after planting and continued until the end of the data collection period. Olaniyi et al. (2005) reported significant increase in the number of fruits and fruit yield of okra when $3 \mathrm{t} / \mathrm{ha}$ of OMF was applied in Ogbomoso. The number of fruits per plant was slightly lower than what was reported by Olaniyi (5.11 - 5.94 fruits per plant). Regular application of organic manure in amounts sufficient to meet the nutrient requirements of crops not only results in increasing the crop yield but also improves the soil fertility and organic matter content (Ramesh et al., 2009) and availability of plant nutrients as compared to chemical fertilizer (Brar et al., 2004). Sandhyarani (1998) reported that the application of higher dose (6t/ha) of castor oil seed cake gave higher yield and uptake of nutrients in radish. Praveen (2000) also reported increased fresh weight of carrot when neem seed cake was applied. Organic fertilizers influence both yield and plant micronutrient contents, and help sustain crop productivity (Mottaghian et al., 2008). Neem seed cake was reported to have increased tomato yield by $15 \%$ compared to the control in SoussMassa region, Morocco (Laghdaf, 2004). The number of green fruits per plant and fruit weight per chilli pepper increased significantly with the application of NSC (Khan et al., 2012).

The effects of neem seed cake on the yield parameters of okra in 2012 are presented in Table 4.
Data on the number of fruits per plant showed that there was increase up to the highest rate applied (4tons/ha). Data on the weight of fruits per plant indicated that there was a significant increase $(\mathrm{P}<0.05)$ in the fruit weight per plant up to an optimum rate of 3tons/ha applied.The result on the fruit diameter showed that the application of $3 \mathrm{t} / \mathrm{ha}$ produced fruits with the widest diameter. NSC significantly $(\mathrm{P}<0.05)$ increased the number of fruits per plant, length of fruits per plant, fruit weight per plant and fruit weight per hectare up to the highest rate applied.However, NSC increased the fruit diameter up to the optimum at 3t/ha. Data on the yield parameters of okra in 2013 is presented in Table 5. The data indicated that the application of NSC was significant $(\mathrm{P}<0.05)$ for all parameters evaluated. It followed a similar trend as the 2012 planting. Data on the effects of number of fruits per plant, weight of fruits per plant, fruit length, diameter and weight per hectare indicated that there was a significant difference between the treated plots and the control except the fruit diameter. The data indicated that as the rate of application increased, there was an increase in the yield parameters. It has been observed by Jha and Rathore (1984) that the dissolution of minerals in the soil takes place at increased rates in the presence of organic fertilizers. The nutrients are released slowly thus making them available to the plants for a longer period (Uma and Poktiriya 1997) .

Table 5: Effects of neem seed cake on the yield and yield components of okra in 2013

\begin{tabular}{|c|c|c|c|c|c|}
\hline${ }_{1}^{\text {Neem seed cake } t \text { ha }}$ & $\begin{array}{l}\text { Number } \\
\text { fruits/plant }\end{array}$ & $\begin{array}{l}\text { Weight } \\
\text { fruits/plant }(\mathrm{g})\end{array}$ & Fruit length $(\mathrm{cm})$ & Fruit diameter $(\mathrm{cm})$ & $\begin{array}{l}\text { Fruit weight/ ha } \\
(\mathrm{t} / \mathrm{ha})\end{array}$ \\
\hline 0 & 2.46 & 30.90 & 6.28 & 1.63 & 3.44 \\
\hline 1 & 2.88 & 47.10 & 6.90 & 1.70 & 5.24 \\
\hline 2 & 3.26 & 58.00 & 7.47 & 1.80 & 6.44 \\
\hline 3 & 5.69 & 118.80 & 7.60 & 1.83 & 13.20 \\
\hline 4 & 5.63 & 120.80 & 7.53 & 1.80 & 13.37 \\
\hline Mean & 3.98 & 75.00 & 7.16 & 1.75 & 8.34 \\
\hline LSD $(\mathrm{P}<0.05)$ & 1.438 & 12.91 & 0.467 & 0.044 & 1.438 \\
\hline
\end{tabular}




\section{CONCLUSION}

The result of the experiment clearly shows that the use of organic materials can be gainfully employed in soil fertility restoration by small-scale farmers, especially neem seed cake. Neem seed cake can reduce the mining of soil nutrients and improve overall crop productivity. Neem seed cake, has a long term effect of building the organic matter content of soil which helps in improving the soil physical properties and hence the increase in the nutrient status of soils. It can therefore be used in areas where the soils are very impoverished. Application of neem seed cake will also have a long lasting effect on the soil and increase the activities of macro and microorganisms and help in building up micronutrients, which inorganic fertilizers cannot supply.

\section{REFERENCES}

Adeoye, G. O.; Ade Oluwa, O.O, Oyekunle, M.; Shridhar, M.K.C.; Makinde, E. A. and Olowoake, A.A. (2008).Comparative evaluation of organomineral fertilizer (OMF) and mineral fertilizer (NPK) on yield and quantity of maize. Nigerian Journal of Soil Science 18:132 - 137 .

Aderni, N. D. (2006). Mixed paper mill sludge effects on corn yield, nitrogen efficiency and soil properties. Agronomy Journal 198: 1471 1478.

Asiegbu, J. E. (1987). Influence of planting date on the growth and productive life of fluted pumpkin.Tropical Agriculture (Trinidad) 16: $281-284$.

Azim, K.; Ferji, Z and Kenny, L (2011). Nematicidal and Fertilizing Impact of argan, castor and neem seed cake on organic cucurbits ( cucumber and melon) grown under greenhouse in Agadir Region ( South Western Morocco ).

Brar, B. S., Singh, M.V., Dhillon, N.S. and Benipal, D. S. (2004). Soil Quality, Crop Productivity and sustainable Experiences under Long-term Maize-wheat-cowpea Cropping. In: "inseptisol research bulletin", Department of soil, Punjab Agricultural University, Ludhiana, Punjab, India. PP. 1-90

Bremner, J. M. (1965). Total N: In: C. A. Black (ed) Methods of soil analysis part 2, Agron. No 9. American society of Agronomy Madison, Wisconsin. 1149-1178.

Das, A., Prasad, M., Shivay, Y. S. and Subha, K. M. (2004). Productivity and Sustainability of Cotton (Gossypium hirsutum L.)-wheat (Triticum aestivum L.) Cropping System as Influenced by Prilled Urea, Farmyard Manure and Azotobacter. J.Agron. Crop Sci. 190: 298304.

Gaur, A. C., Neelakanthan, S. and Dargah, K. S. (1992). Organic manures. Indian Council of Agricultural Research, New Delhi, pp.157.

Grubben, G. J. H. and Denton, O. A (2004). Plant Resources of Tropical Africa 2. vegetables. PROTA Foundation, Wageningen, Backhuys publishers, Leiden, Netherlands C T A Wageningen, Netherlands 667pp.

IFA, ( 1992). World Fertilizer Use Manual. Eds. D. J. Halliday and M. E Trenkel. 632 pp

Ikeh, A.O.; Ndaeyo, N.U. ; Akpan, E. A.;Uko, I.U. and Bassey, D.E. (2013). Response of okra (Abelmoshus esculentus L Moench) cultivars to composted market refuse rates and NPK in wetland dry season farming. Proceedings of the $1^{\text {st }}$ National Conference of the Crop Science Society of Nigeria (CSSN) held at the University of Nigeria Sept $15-19^{\text {th }}, 2013$.

Isherwood, K. F. (2000). Fertilizer use and the Environment. International Fertilizer Industry Association. Revised Edition, Paris , Paris, France February,2000.

Jha, M. N. and Rathor, A. K. G (1984). Soil organic matter in biomass determination. Indian Forester $110: 895-900$.

Korah, P. A. and Shingte, A. K. (1968). On the effect of non edible oil cakes on the respiratory activity of soil. Agricultural Research Journal of Kerala, India 6: 95 - 97.

Khan, Z.; Tiyagi, S.A.; Mahmood I. and Rizvi, R. (2012). Effect of $\mathrm{N}$ fertilization, organic matter, and biofertilizers on the growth and yield of chilli in relation to management of plant parasitic nematodes.Turkish Journal of Botany 36:73-81.

Kumar S, Singh D and Nepalia, V. (2009). Performance of Fenugreek (Trigonella foenum-graecum) varities at various fertilizer levels and biofertilizer inoculations. Indian $J$ Agr Res 79: 80-83.

Kumar, S. and Khanna, A.S (2006): Role of Trichoderma harzinum and Neem cake separately and in combination against Rootknot nematode. Indian Journal of Nematology 36(2): 264-266.

Kuo, S. (1996). Phosphorus. In methods of soil analysis. Part 3 Chemical methods. D. L. Sparks (Ed.) American Society of Agronomy, Madison pp 869 - 919.

Laghdaf, T. (2004). Effet des amendements organiques et quelques produits chimiques et

biosynthétiques sur les nématodes à galles de la tomate dans le Souss-Massa. Mémoire de fin 
d'étude,Phytiatrie, 3ème cycle, IAV Hassan II. Complexe Horticole d'Agadir pp : 69-79.

Lei, Meng, Weixin Ding and Zucong Cai (2005). Long term application of organic manure and nitrogen fertilizer on $\mathrm{N}_{2} \mathrm{O}$ emissions, soil quality and crop production in a sandy loam soil. Soil Biology and Biochemistry 37: 2037 2045.

Meena, P.; Nehra, S. and Trived, P. C. (2009). Efficacy of decomposed cakes against Heterdera cajani infecting Cajanus cajan. Asian Journal of Experimental Science 23:181 - 184

Mottaghian A, Pirdashti H, Bahmanyar MA \& Abbasian A (2008). Leaf and seed micronutrient accumulation in soybean cultivars in response to integrated organic and inorganic fertilizers application. Pakistan Journal of Biological Sciences 11: 1227-1233.

Ndaeyo, N. U. ; Edu, S. U. and John, N. M. (2005). Performance of okra as affected by organic and inorganic fertilizer on an ultisol. Proceedings of the $39^{\text {th }}$ Conference of the Agricultural Society of Nigeria, University of Benin, Oct. $9^{\text {th }}-13^{\text {th }} 2005$ pp $206-209$.

Nelson, D. W. and Sommers, L. E. (1996). Total carbon, organic $\mathrm{C}$ and organic matter. In D. L. Sparks ( Ed.) Methods of Soil Analysis. Part 3 Chemical method, SSSA Book series Number 5, Madison, W.I. Am. Soc. Agron.

Olaniyi, J. O; Ogunrinde, J. O., Olabode, O. S and Akanbi, W. B. (2005). Effect of organic mineral fertilizer Application on growth, yield and nutrient uptake of Maize. Journal of Applied Agricultural and Apicultural Research, 2(1):10-19

Parmar, B. S. (1986). An overview of neem research and use in India during the years $1883-1986$. Proceedings of $3^{\text {rd }}$ International Neem Conference. Nairobi Kenya. German Agency Technical Cooperation, Deutsche Gesellschaff furtchnische Zusammenarbeit ( GTZ) . Eschborn Germany. Pp 55-80

Phicot, J.; Sedogo, M.P and Arrivers H.P. (1981). Evaluation de La Fertilite Dun Ferrugineux tropical sous L. influence $\mathrm{Du}$ Femures Minerales et organiques L Agrronomic Tropicale, 36(2) : $122-133$

Praveen Kumar, Y. (2000). Conjunctive use of castor cake and nitrogenous fertilizers on the performance of carrot. M.SSc. (Agric) thesis, Acharya N. G. Ranga Agricultural University, Hyderabad, India.

Radwanski, S. A. and Wickens, G. E. (1981). Vegetative fallows and potential value of the neem tree in the Tropics. Economic Botany 33: $398-414$.
Ramesh, S., Balakrishna Gowda, Raghu, H.B. and Shivakumar, B.C. (2009). Manurial value of byproducts of bio-fuel feed stocks on finger millet grain and dry fodder productivity. Journal of Applied and Natural Science: 1(2):241-249.

Rizvi, R.; Mahmood, I.; Tiyagi, S. A. (2013). Potential role of organic matters and phosphate solubilizing bacteria (PSB) on the growth and productivity of fenugreek. Journal of Agricultural Science Technology 15: 639 647.

Sandhyarani, G. (1998). Effect of integrated nutrient management with castor cake and nitrogenous fertilizer on growth and yield of radish (Raphanus sativus L.) M. Sc. (Agric) thesis, Acharya N. G. Ranga Agricultural University, Hyderabad, India.

Schippers, R.R.(2000). African Indigenous Vegetables, Netherlands PP103-118.

Shivakumar, B. C.; Girish, A.C.; Balakrishna Gowda; Vijaya Kumar, G. C.; Mallikarjuna Gowda, A. P. and Thimmegowda, M. N. ( 2011).Influence of Pongamia, Mahua and neem seed cakes on finger millet productivity and soil fertility. Journal of Applied and Natural Science 3: $274-276$.

Singh, S. P., Veena, A.M. Khan, and S.K. Saxena. (1986). Changes in the phenolic contents, related rhizosphere mycoflora and nematode population in tomato inoculated with Meloidogyne incognita as a result of soil amendment with organic matter. Indian Journal of Nematology $15: 197-201$.

Singh, Y.; Singh, C. S.; Singh, T. K. and Singh, J. P. (2006). Effect of Fortified and Unfortified Rice-straw Compost with NPK Fertilizers on Productivity, Nutrient Uptake and Economics of Rice (Oryza sativa). Indian Journal Agronomy 51: 297-300.

Sivaprakashan, K. (1991). Soil Amendment for Crop Disease Management. In: "Basic Research for Crop Disease Management", (Ed.): Vidyasekharan, P.. Day Publishing House, New Delhi, India, PP. 382-404.

Smith, M. A. K ; Tolorun, T. P. and Adeniji, O. S . (2001). Effect of combined mulch and fertilizer on weed growth and okra (Abelmoshus esculentus L. Moench) yield in Tropical environment. In; Proceedings $35^{\text {th }}$ Annual conference of the Agricultural Society of Nigeria held at University of Agriculture, Abeokuta, Nigeria Sept 16 - 20, 2001. Pp 103- 112.

Soon, L. G. and Bottrel, D. G (1994). Neem pesticide in rice. Potentials and limitations. 
International Rice Research Institute, Manilla Philippinespp 75-91'

Steel, R. G. D. and Torrie, J. H. (1980). Principles and Procedures of Statistics with Special Reference to the Biological Sciences McGraw Hill Book Co. Inc. New York 481pp.

Sunanda Rani, N and Mallareddy M. (2007). Effects of different manures and inorganic Fertilizers on growth yield and quality of carrot. Karnataka Journal of Agriculture Science 20 : 686 - 688.

Tiyagi S.A. and Ajaz, A. (2004). Biological control of plant parasitic Nematode associated with Chikpea using Oil cakes and Paecilomyces lilacinus. Indian J., 34(1), 44-48.

Tiwari, K.N. (2002). Nutrient Management for Sustainable Agriculture. J. Ind. Soc. Soil Sci., 50: $374-377$

Udo, I. O. and Akpan, E. A. (2002). Response of okra cultivars to investigation of flea beetle (Podagrica uniforma) Jack in Southern Nigeria. Journal of Sustainable Tropical Agricultural Research. 3:40 - 44
Uma Singh and Gurumurti K (1984). Oil cake from oil seeds of forest origin their potentials as fertilizer. India Journal of Forestry 7:12 - 18

Uma Singh and Pokhriyal, T. C (1997). Effects of deoiled tree seed cakes and growth and biomass production in Dalbergia sissoo seedlings. Proceedings India National Science Academy B63 No. 6 pp 625 - 630

Uma Singh; Rawat, P. S. and Purohit, C. K. (1986). Dry matter production in response to application of tree seed oilcake as fertilizer in Leuceana leucocephala. India Journal of Forestry 10: $214-216$.

Wilkinson, S. R. (1979). Plant nutrient and economics value of animal manures. Journal of Animal Science 48: 121 - 133 .

Yusuf, A. A.; Iwuafor, E. N.O.; Ladan, Z.; Agbaji, A. S.; Abdusalam, $Z$ and Yusuf H.A. (2011). Evaluation of neem based compound fertilizer for crop production in Samaru, moist savanna of Nigeria. Journal of Agricultural Science and Technology (2011) 235 - 243. 